\title{
Spatial and Temporal Pattern of Flood Area in Cisadane Watershed, Banten Province
}

\author{
Mangapul P.Tambunan \\ Lecturer in the Department of Geography \\ Faculty of Mathematics and Natural Sciences \\ University of Indonesia \\ Depok, Indonesia \\ Corresponding email: mangapul.parlindungan@ui.ac.id and mptgeoui@gmail.com \\ Tjiong Giok Pin \\ Lecturer in the Department of Geography \\ Faculty of Mathematics and Natural Sciences \\ University of Indonesia \\ Depok, Indonesia \\ Bintar Permana \\ Graduate student in the Master of Geography \\ Faculty of Mathematics and Natural Sciences \\ University of Indonesia \\ Depok, Indonesia \\ Ahmad Zikrullah \\ Graduate student in the Master of Geography \\ Faculty of Mathematics and Natural Sciences \\ University of Indonesia \\ Depok, Indonesia \\ Agus Maulana \\ Undergraduate student in the Department of Geography \\ Faculty of Mathematics and Natural Sciences \\ University of Indonesia \\ Depok, Indonesia
}

\begin{abstract}
Spatial and temporal study was conducted in flooding the watershed of Cisadane, Province Banten. This study aims to: (1) to study the spatial distribution of the target area flooding potential and actual, and (2) to study the distribution pattern of flooding in the watershed Cisadane, Province Banten. Flood studied from the fields of geography by using a spatial approach. The collection of data obtained through the physical condition of landforms interpretation of topographic maps, Geological map, and RBI map. Data flooded area (area, depth and length) were obtained from the survey and the data obtained from the flood events Infrastructure (PU) DAS Cisadane, Province Banten, rainfall data obtained from BMKG. Analysis of the distribution of the flood and the targets do spatially and temporally using the tools of the Geographical Information System (GIS) while the rainfall analysis was done descriptively on a scale of 1: 50,000. The result of the alleged research shows that 1) the target area potential flood is not always followed by the actual floods. Current flood prone area located in the middle and lower reaches of the watershed Cisadane, Province Banten. Prone areas of potential flooding in the flat slopes, ramps up rather
\end{abstract}

steep contained in alluvial fans, alluvial plains, shoals beach and coastal alluvial plain; and 2) there are variations in the spatial and temporal distribution pattern of flooding area in Cisadane Watershed.

Keywords - Rainfall, flooding areas of spatial, temporal flooded areas, landform, and Cisadane Watershed, Banten Province

\section{INTRODUCTION}

Indonesia has 5,590 main rivers where there are 600 rivers or $10.7 \%$ potential flooding even flooding to the area floods could reach 1.4 million hectares. In October 2001 and February 2002 there are 92 huge flood that inundated settlements 54482 hectares or $3.89 \%$ of the total area of the flood (JICA, 2001; Ministry of Public Works, 2002b) 
Total area of the watershed Cisadane 150,630.305 (Ha), this watershed surrounding the Bogor Regency, Bogor, Tangerang City and Tangerang regency is divided into three segments, namely: The upstream watershed area of 112,093.50 hectares Cisadane mostly include the district of Bogor, The middle of DAS Cisadane area of 20264.68 hectares, including areas from the downstream area of 16324.50 hectares including administrative area of Tangerang Regency, consisting of the District of Mauk, Sepatan, Teluk Naga, Paku Haji, Benda, and Kosambi. Land use in Banten Province reached $93.44 \%$ of the total area of alluvial landscape. In fact, the use of land for settlement reached $69.86 \%$ of the total built area of land use which is equivalent to $65.27 \%$ of the total. In addition, damage to agricultural land use and wetlands is reservoir/lake / Situ acting as water retention and water reservoirs (retarding basin) for settlements and their facilities, assumed to be the cause of the increase and spread the intensity of floods in the lowlands in Tangerang district patterned as a flood prone area

Based on the background and the problems of flooding in the watershed area Cisadane, Banten Province, the formulation of research problems are as follow how spatial and temporal distribution pattern of flooding actual target area?

This study aims to assess the spatial and temporal distribution pattern of actual flooded areas. Framework built in research in the watershed Cisadane, Banten province, on the basis of the climate concept precipitation (thickness, intensity and distribution), the concept of landforms, the concept of flooded areas, and the concept of land use. The climate is represented in the form of precipitation in the watershed Cisadane, Banten Province.

The results of this study are expected to be useful as information for policy-makers and decision makers in the provincial, district and city at the time of formulating the direction of implementation of development activities. In the spatial arrangement of land settlement and facilities on a scale (1: 50,000) should be adapted to the local environment of flooding, watershed Cisadane, Banten Province

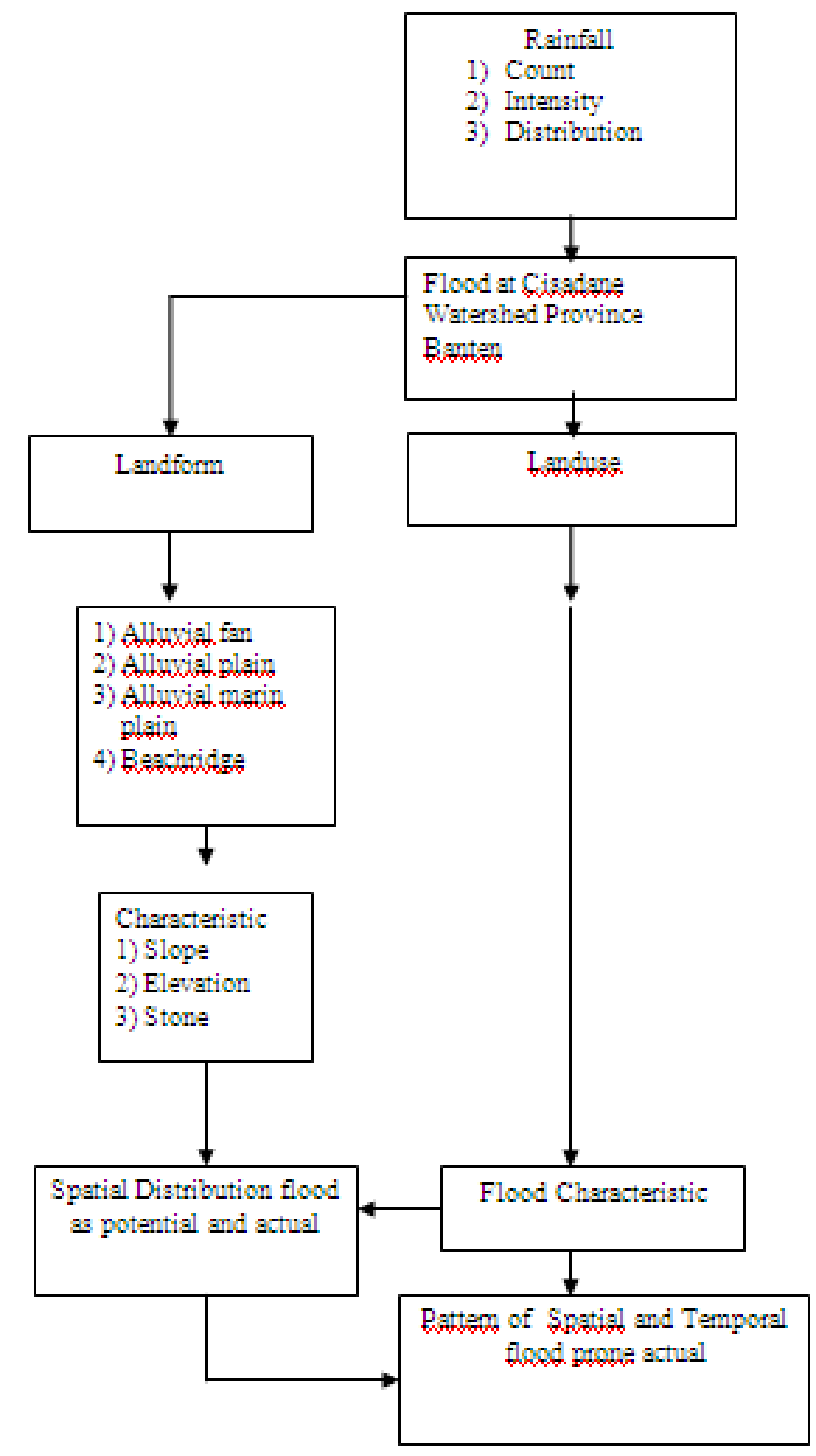

Fig. 1. Flow chart of theoretical Framework

\section{RESEARCH METHOD}

\section{A. Study Approach}

This study uses a survey approach pragmatic, because the object studied is associated with flooding. In a survey pragmatic directed to solve problems, in this case is the problem of flooding. The data used in the survey is pragmatic geomorphological survey data analytic and synthetic survey.

\section{B. Selection of Research Area and Time}

Assumptions of the real (empirical) used in selecting areas that flooded sub-districts are as follows:

- flood due to high daily rainfall;

- frequently flooded area 
- there are differences and similarities in the characteristics of the floodplain areas subject to flooding;

- population (density and distribution) is relatively large;

Flood events discussed in this study is limited to the major flooding that occurred in February of 2014. By reason of the spatial distribution of flood events is the most extensive and diverse and also shows the temporal aspect (Figure 2).

\section{Materials and Research Equipments}

Materials research includes all data related directly and indirectly with the study landform, rainfall, and the floods in Banten and west Java province. Research tools used include geological surveying equipment such as geological compass, GPS, helling, altimeter, current meter, flood depth ruler, digital cameras, and motorcycles. Research tools that come from government agencies. measuring equipment in the form of rain is rain gauge manual instrument for daily rainfall data from the BMKG agency, equipment for river water discharge data, and high river water from the Irrigation Department of the Provincial Government of Banten.

\section{Research Variables}

- Variable of landform parameters analyzed were relief (altitude and slope), b. material, and c. geomorphic processes.

- Variable of floods analyzed were flood sites (subdistricts), flood area (hectares), depth of flooding ( $\mathrm{cm})$, and d. long flood (hour).

\section{E. Data Collection}

Primary data collection was done at the time of field survey in landform DAS Cisadane

Banten is as follows:

- $\quad$ survey of flood location with a visit to the field.

- $\quad$ survey flood depth is noticed of marks on the walls of homes flooded as water limits the depth flood.

- survey of the flood area is obtained from measurements in the sub-district flooded by using GPS devices, and BPBD.

the survey asked when the old flood flooding and how long homeowners flood events to residents who experienced flooding in their respective units of landform.

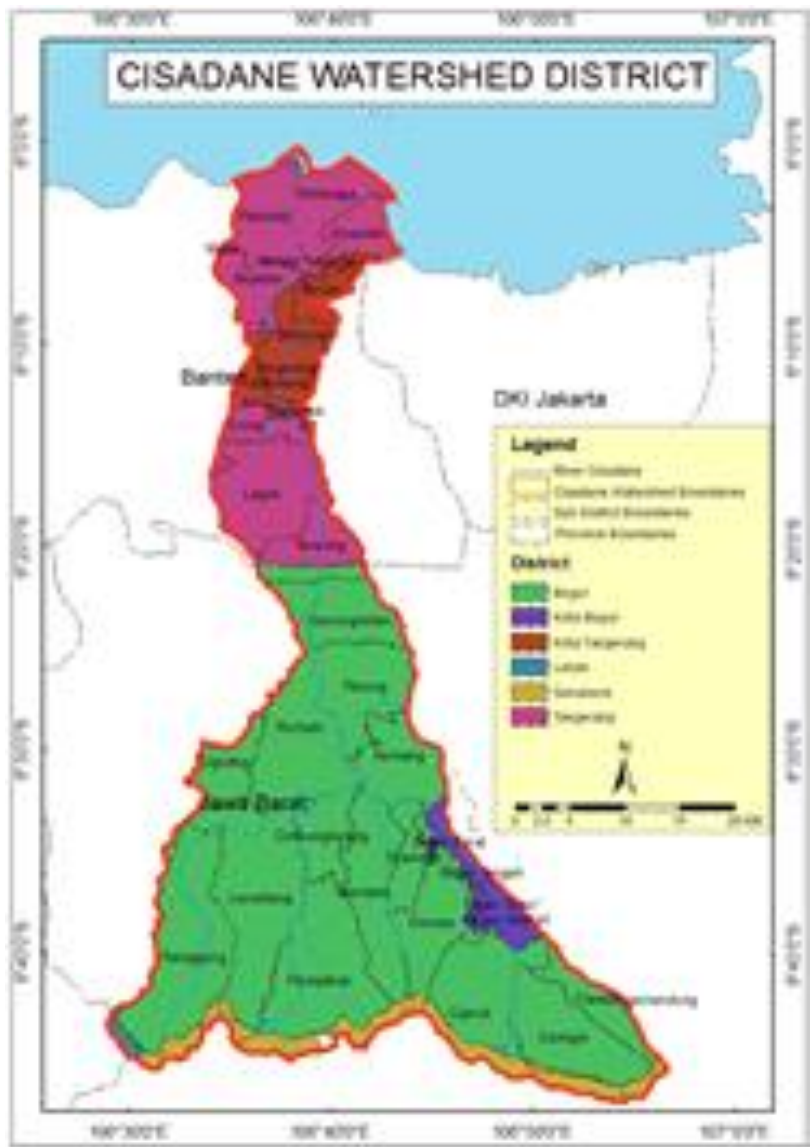

Fig. 2. Cisadane Watershed District

\section{FINDING AND DISCUSSION}

Before you begin to format your paper, first write and save the content as a separate text file. Keep your text and graphic files separate until after the text has been formatted and styled. Do not use hard tabs, and limit use of hard returns to only one return at the end of a paragraph. Do not add any kind of pagination anywhere in the paper. Do not number text headsthe template will do that for you.

Finally, complete content and organizational editing before formatting. Please take note of the following items when proofreading spelling and grammar:

\section{A. Distribution of Spatial Slope}

Characteristic for upper course region Cisadane watershed has made as:

- Letter V-shaped valley

- Predominantly erosion

- Interlocking spurs

Region is west Java province included Bogor residence (West Java Province)

Middle course region Cisadane watershed has made as:

- Letter U-shaped valley

- Landforms meanders

- Transportation of water and sediments 
Region is South Tangerang and Tangerang Cities (Banten Province)

Characteristic for lower course region Cisadane watershed has made as:

- Letter U-shaped valley

- Predominantly erosion

- Interlocking spurs

The region is Tangerang city (Banten Province).

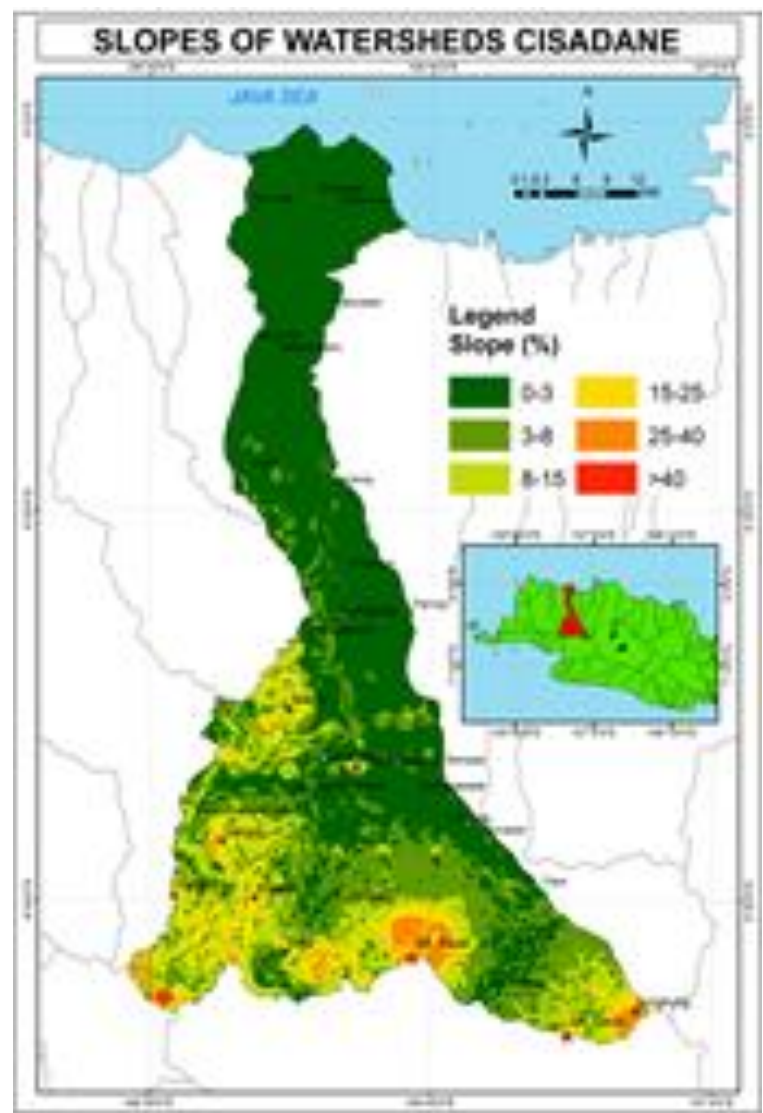

Fig. 3. Map Slope of Watersheds Cisadane

Slopes in the Das Cisadane class or six classes divided Slopes slope where the lowest grade $(0-3 \%)-(\geq 40 \%)$, where the hump is dominated class flat slope (0-3\%). This flat grade spreads in the downstream, midstream and upstream watershed Cisadane slightly. While on the upstream side of the land there are more choppy and bumpy. The mountain areas in the district such as the flute, dango, and Lingkung slope of the land in the form of land hilly to steep

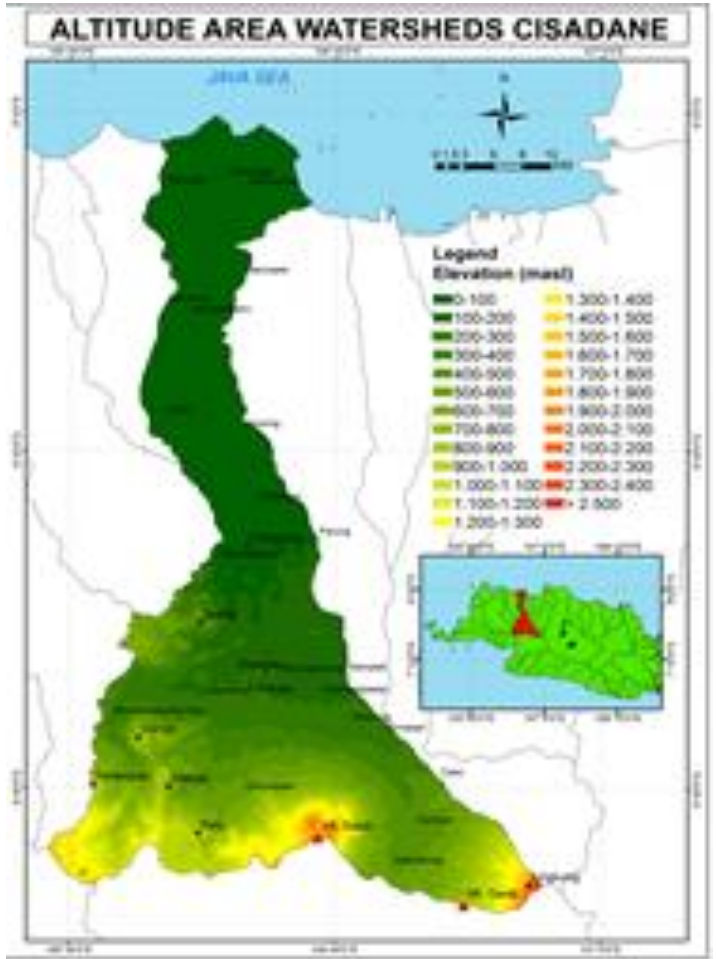

Fig. 4. Map Altitude of Watersheds Cisadane

Class divisions Cisadane elevation in the watershed is divided into 25 classes. Cisadane watershed is dominated by areas with altitudes of 100 meters above sea level, especially in the upstream (Kab. Bogor). While at the height of the downstream region is 0 to 100 meters above sea level. This is because the upstream area is an area that is close to or directly adjacent to the sea (beach).

TABLE.1 FLOOD HAZARD CISADANE

\begin{tabular}{|c|r|r|r|r|r|}
\hline \multicolumn{7}{|c|}{ FLOOD HAZARD CISADANE } \\
\hline Segmen & \multicolumn{1}{|c|}{ Low } & \multicolumn{1}{|c|}{ Middle } & \multicolumn{1}{c|}{ High } & Total (Ha) & \multicolumn{1}{c|}{$\%$} \\
\hline Upper & 42122.07 & 69668.08 & 111790.2 & 23580.3 & 76.3 \\
\hline Middle & 65 & 196.7 & 196.7 & 58.4 & 0.2 \\
\hline Lowland & 19.2 & 30198.1 & 38627.17 & 68844.47 & 23.5 \\
\hline Total (Ha) & 42206.27 & 100062.9 & 150614 & 292883.17 & \\
\hline (\%) & 14.4 & 34.2 & 51.4 & $100(\%)$ & $100(\%)$ \\
\hline
\end{tabular}

\section{B. Comparative Potential and Actual in Flood Prone Area}

Flood-prone areas in flood plains, coastal alluvial plains and alluvial plains wider, deep and long compared alluvial fan. Spreading flood prone areas flood in downstream watershed Cisadane, Topography in flood-prone areas on the slopes of flooding is a flat basin with a surface elevation of less than $3 \mathrm{~m}$ above sea level. Beach ridge located in the northwest and northeast of the Tangerang District, where the tendency is landform direction perpendicular to the coastline. Distribution 
flooded area of beach ridge increasingly widespread, high and long in flat slope for very flat compared to the rather steep slope.

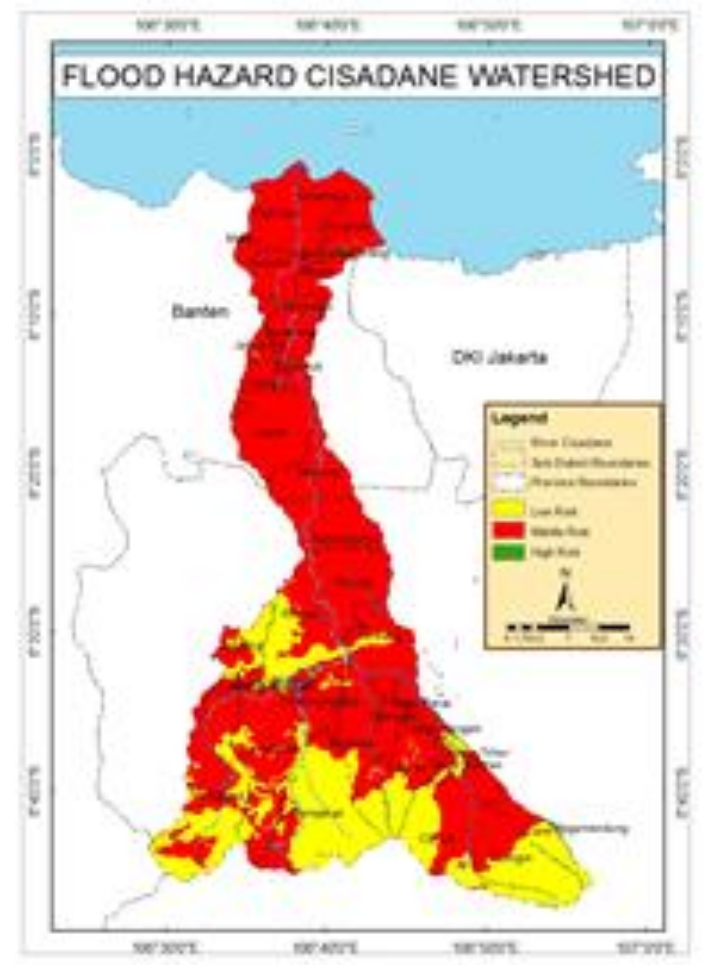

Fig 5. Map Flood Hazard Watersheds Cisadane

Of flood vulnerability maps created based on a map - a map of the flood is found that the deciding factor Watershed (DAS) Cisadane consists of three classes of vulnerability to flooding, namely: grade Highly Prone (0.24138 Ha / 0:16\%), class Rawan $(90.8195 \mathrm{Ha} / 60.2 \%)$, Somewhat Prone $(59.8021 \mathrm{Ha} / \mathrm{39.64 \% )}$, Flood Hazard Class Number Percentage $(\%)$ area $(\mathrm{Ha})$

Parts or segments that there are many regions that are particularly vulnerable class is downstream with area 68844.47 hectares. The middle part is a part that has a class with a comprehensive secure the highest of 58.4 hectares. This is because the central area is an area with a predominantly land cover plantation, where forest and plantation forest cover has a great influence in preventing flooding

Districts that have a broad class of vulnerability is very vulnerable to the highest are Teluk Naga sub-district (4654.25 ha) followed Pagedangan (4639.52 ha), and Paku Haji (4605.53 ha). This area has a flood-prone area is very spacious influenced by factors: slope class that is generally flat (0-3\%), high grade with an altitude range from 0 to 12.5 meters above sea level, soil texture with criteria Very smooth, drainage impeded, and Closure the land is dominated by rice fields, settlements and water bodies.

Identification of changes in land use in a watershed is a process of identifying differences in the presence of an object or phenomenon observed at different times in the basin.
Identification of changes in land use requires a temporal spatial data. Spatial data is sourced from the analysis of the image as well as government agencies such as the BIG.

Cisadane current watershed conditions have exceeded the carrying capacity. This situation is due to the high population and lack of land that is water absorbent. The purpose of this study was to quantify changes in land use in the watershed Cisadane from 2005 to 2010 and predicting the area change land use in 2005, 2010 and 2015

TABLE.2 CLASS FLOOD HAZARD CISADANE

\begin{tabular}{|r|c|r|c|}
\hline No & Class Flood Hazard & Percentage (\%) & area (Ha) \\
\hline 1 & 2 & 3 & 4 \\
\hline & & 0.16 & 0.24138 \\
2 & High & 60.2 & 90.8195 \\
3 & Middle & 39.64 & 59.8021 \\
\hline
\end{tabular}

Based on the results of the analysis show that the extensive changes the types of land use in the watershed area Cisadane from 2005 to 2015 the largest is the type of land use Area Built ie increased area of 38625,482 ha or $34.04 \%$ of the total watershed area while land use types Land Open reduced area of 19284,907 ha or $13.62 \%$ of the total watershed area. While the addition of the forest is the result of reforestation in the area Taman Nasional Halimun Salak (TNHS).

Based on the administration area, South Tangerang and Tangerang Regency South is an area that changes in land use types, settlement or area woke most extensive changes from 2005 to 2015 is increased by 150614 ha while the body of water also experienced a reduction in area of 5331,510 ha, but the area changes

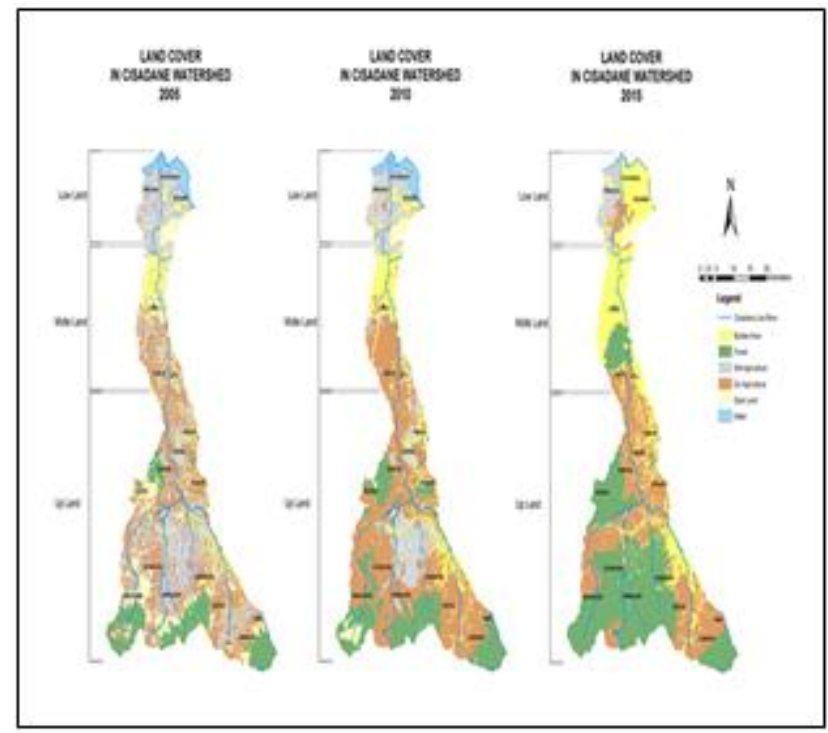

Fig 6. Map Flood Hazard Watersheds Cisadane 
Body of water that is experiencing these changes are only $3.67 \%$ of the area through which the DAS and $32.12 \%$ for dry types of land use of the area through which the DAS Cisadane in the Upstream - Downstream. Percentage change from the widest area of administration through which the DAS Cisadane occurred in the district of Tangerang, namely on land use types and Agriculture Wet Dry Farming is a vast reduction amounted to $62.06 \%$ and changes in land use types into Woke area amounted to $8.68 \%$.

TABLE.3 AREA LAND COVER

\begin{tabular}{|l|l|l|l|}
\hline LAND COVER & $\mathbf{2 0 0 5}$ & $\mathbf{2 0 1 0}$ & \multicolumn{1}{|c|}{$\mathbf{2 0 1 5}$} \\
\hline Builded Area & 13220.818 & 33276.541 & 51846.300 \\
\hline Forest & 18227.764 & 16730.186 & 45386.356 \\
\hline Wet Agricultural & 45601.282 & 25531.133 & 5132.051 \\
\hline Dry Agricultural & 48926.268 & 68839.952 & 48229.430 \\
\hline Open Land & 20750.913 & 3420.980 & 1466.005 \\
\hline Water & 5583.404 & 4513.244 & 251.893 \\
\hline
\end{tabular}

Land Reform Cisadane Watershed land significant changes during the 10 years from 2005 to 2010 mainly regional changes build area increased about 38626 ha, or about $34.5 \%$ of the land area of impact Cisadane DAS building expansion occurring in the uplands - the downstream effect on the reduction in size of the forest and agricultural land which is why the land-use change and therefore caused downstream flooding and erosion in upstream areas

\section{CONCLUSION AND SUGGESTIONS}

The result of the study show that actual of flood prone area in the north, west and east of Tangerang lowland and left-right Cisadane river (middle-upland) both in floodplain, coastal alluvial plain, and alluvial plain; while the flood potential area on the slope is found flat and steep at alluvial fan, alluvial plain, flood plain, and coastal alluvial plain in Cisadane Watershed

\section{REFERENCES}

[1] Asdak, Chay, 2001, "Hidrologi dan Pengelolaan Daerah Aliran Sungai", Gajah Mada University Press : Yogyakarta.
[2] Bappeda Banten, 2009, "artikel mengenai Pengendalian Banjir", dalam web site http://www.bappedajakarta.go.id/jktbangun/asp pada $10.00 \mathrm{wib}$ (18 Maret 2009).

[3] Bemmelen, R.W, van, 1970, "The Geology of Indonesia", Vol IA General Geology, Martinus Nijhoff the Netherland: The Hague

[4] Dinas Pekerjaan Umum Provinsi Banten, 2008, "Data dan Penjelasan Area Banjir di Jakarta”, Pemda Banten.

[5] Japan International Cooperation Agency, Direktorat Jenderal Pengembangan Sumber Daya Air Departemen Pekerjaan Umum Republik Indonesia, 2002, Studi On Urban Drainage And Wastewater Disposal Project In The City Of Jakarta.

[6] Kodoatie, Robert J et al, 2010, "Tata Ruang Air", Penerbit Andi : Yogyakarta

[7] Verstappen, H.Th., 1953, Djakarta Bay, "a Geomorphological Study on Shoreline Development" Doctoral Thesis, Univ. Utrecht, Drukkerij Trio's Gravenhage, The Netherlands.

[8] Verstappen, H.Th., 1983, “Applied Geomorphology, Geomorphological Surveys for Environmental Development" Amsterdam: Elsivier.

[9] Verstappen H.Th., 2000, "The outline of the Geomorphology of Indonesia: A case study on tropical geomorphology of a tectogene region" ITC Publ, No.79. Enschede, The Netherlands 